\title{
Asian Retailers in Glasgow: A Glimpse of Commercial and Property Relations in the Early Eighties
}

\author{
MOHAN LUTHRA
}

Retired UK based Academic and Civil servant, United Kingdom.

\begin{abstract}
As noted in the paper published in the last issue of this journal, shopkeeping and retail has been one of the important ways of entry into the host economy in the case of some pre-war migrating communities such as the Jewish and the Italian heritage communities and relatively recently the post war migrants such as the Asians (mostly Panjabis from both India and Pakistan) to Glasgow in Scotland. I explore how the two major ethnic enterprise related theories ie the ethnic customer niche and middlemen minority theories apply to this group and also enter the unchartered area of the nature of 'property relations' of retailers, i.e. acquisition of both commercial and housing property. Specifically, the paper explores the similarities and differences between the commercial and residential markets and their relationship and possible interdependence for entrepreneurial and asset building by the settlers as well as the phenomenon of segregated property markets. I begin by exploring the background of retailers and its possible influence on entry into the business. The paper also compares some key aspects of Glasgow's Asian retail economy with other Asian retail localised economies using the studies of the period for comparative perspective purposes. The paper adds to the very sparse literature on asset owner ship or on ethnic commercial property markets and explores if the observed high ownership of residential property and the role of country-of-origin national banks in assisting with both ethnic enterprise and asset creation. The paper also explores the hypothesis if the agricultural background of many settlers which requires some sense of business and related skills, and the status accorded to property may be the crucial explanatory cultural factors of asset acquisition and enterprise.
\end{abstract}

\section{Introduction}

Light catalogued graphically the development of small enterprise among both the Chinese

and the Japanese communities and contrasted it with the Black communities in the US adding and taking forward the research undertaken by

CONTACT Mohan Luthra $\gg$ luthramohan@hotmail.com 9 Retired UK based Academic and Civil servant, United Kingdom.

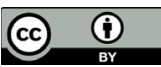

C 2021 The Author(s). Published by Enviro Research Publishers.

This is an $\partial$ Open Access article licensed under a Creative Commons license: Attribution 4.0 International (CC-BY).

Doi: $10.12944 / C R J S S H .4 .2 .03$ 
Blalock (1967:79-84), and Bonacich (1973) ${ }^{1}$ in historical economic development of minorities in a comparative context. He emphasized the reliance of early retailers on ethnic food stuffs on ethnic customers and outlined internal systems of accumulating capital, mutual co-operation stemming from ethnic solidarity and voluntary associations. Over the years the Chinese economy appears to have moved from 'ethnic enclave' model to that of 'middle minorities' model, he noted.

The concept of "middleman minorities" developed by Blalock encompassing such groups as the Chinese in Southeast Asia, Jews in Europe, and Indians in East Africa explains the development and persistence of the form. A key variable is the orientation of immigrants towards their place of residence, with sojourning at first, and later a "stranger" orientation affecting the solidarity and economic development of the ethnic group often invoking hostility of the host society, fostering resistance to assimilation, often acquiring "stranger" status.

Similar parallels have been drawn here in the UK in various studies. ${ }^{2}$ Key characteristics of Asian retailers cited in most English studies can be summarized as following:

(a) The Asian businesses overwhelmingly tend to be in inner cities and usually concentrated in some sectors such as retail (groceries, off licenses etc.).

(b) They have reasonable access to bank funds (unlike the Caribbeans) with significant reliance on savings.

(c) Being relatively younger entrepreneurs and in many cases being part of the extended family their disposal growing family labour including that of the spouse and to some extent children. They have a very limited job creation capacity.

(d) Usually, they rely on a "niche" of ethnic customers, which is assisted by their location and have an enclave rather than a middleman economy.

(e) They keep their business going by opening at unsocial hours often with poor returns in terms of hours invested.

(f) They are likely to have more education and are slightly more likely to come from a business background than their white counterparts.
Most never considered an alternative to their business nor do they appear to have been pushed into retail. There is little evidence from surveys that discrimination is a key push factor.

(g) Benefits accrued are intangible, e.g., independence, status, and benefit to customers.

In profiling the retailers, we examine the evidence regarding these observations and benchmark these against the above assumptions.

In this paper i begin by examining the background and origins of retailers in terms of previous occupation, education both in Glasgow and the country of origin. This is followed by examination of business operation, the evidence in relation to the ethnic niche model followed by the way the business is established and capitalised. The second half of the paper focuses on examining property relations in a commercial context including business location, tenure spatial distribution and compare it wherever possible to residential property aspects. The final section of this paper compares some key features of Glasgow Asian Retail economy with observation from studies made in other areas followed by benchmarking against middlemen minorities features.

The data sources for this paper are drawn mainly from Krcmar's survey of retailers which was undertaken just before my own household survey, at the same time which enabled me to use a subsample of the self-employed retailors. Self- employed subsample was extracted from this survey In addition, the Valuation Roll data regularly published by the local authority was gleaned by using name recognition. The term 'Asian' has been used to refer to those ethnic minority groups with origins in South Asia, i.e., India, Pakistan, Bangladesh, and Sri. Lanka. It also includes those of Asian descent who previously lived in the East African countries. We have used the term Scottish for non- Asians White retailers.

\section{Background of Asian Retailers}

As stated earlier the self-employed Asian heads of households constituted $30 \%$ of the Asian households in my household survey mostly nonprofessionals, a figure much higher than the averages in London. Among the self-employed heads of household's 
retailers constitute $70 \%$ suggesting significant lack of diversification in the Asian self-employed businesses (Table 1). restaurant /catering and shop keeping being the two key sectors accounting for majority of the Asian self-employed. Amongst businesses which were reported to be growing during the mid-eighties the likely candidates are catering, shop keeping and the video hire trade. ${ }^{5}$

Table 1: Type of self-employed Business

\begin{tabular}{lccc}
\hline & $\begin{array}{c}\text { Indian } \\
(\%)\end{array}$ & $\begin{array}{c}\text { Pakistani } \\
\mathbf{( \% )}\end{array}$ & $\begin{array}{c}\text { Asian } \\
\mathbf{( \% )}\end{array}$ \\
\hline Shopkeeper & - & 17 & 11.9 \\
Newsagent & 47 & 55 & 11.9 \\
Manufac. & - & 5 & 3.3 \\
Wholesale & 6 & 2 & 3.3 \\
Gathering & 41 & 9.5 & 18.6 \\
Warehouse & - & 2 & 1.7 \\
Garage & - & 2 & 1.7 \\
Draper & 6 & 5 & 3.3 \\
Video & - & 2.5 & 1.2 \\
N= & $(17)$ & $(42)$ & $(59)$ \\
& & & \\
\hline
\end{tabular}

*Source Survey - M. Luthra 1982

Of the total sample examined $77 \%$ of the selfemployed were Punjabis. This approximates the proportion in the total Glasgow population of Asians. Approximately half in the sample were East Punjabis from India and one third originated from West Punjab in Pakistan. Clearly, we also had the emerging Scottish born self-employed Asian development which may warrant attention of researchers focusing the nineties. (Table 2) but who were in in a small number at the time.

Table 2: Place of Birth

\begin{tabular}{lc}
\hline Whole Sample & \\
\hline East Punjab & 48.5 \\
West Punjab & 30.6 \\
Kashmiri & 4.5 \\
Scotland & 3.7 \\
Other Subcontinent & 12.7 \\
\hline
\end{tabular}

*Source Survey - M. Luthra 1982
The religious affiliation profile of retailers appears to suggest that the proportion of self- employed is slightly lower among Muslims who traditionally have not been a commercial community (Table 3). To some extent it also applies to the Sikh community and more generally to the Punjabi community. It is a remarkable adaptation for what are essentially peasant/ agricultural communities.

Table 3: Religion

\begin{tabular}{lcc}
\hline & Self-Employed & Retailers* \\
\hline Muslim-Pakistani & 61.2 & 62 \\
Indian Hindu Sikh & 36.3 & 24 \\
Other & 2.5 & 14 \\
No & 59 & 50 \\
\hline
\end{tabular}

*Source Survey - M. Luthra 1982 *Survey K. Krcmar 1982, MBA dissertation Asian Retailers in Glasgow, Strathclyde University.

In Haq's phone survey of Asian grocers in Glasgow Indians (mainly Hindus and Sikhs) constituted only $21 \%$ of his sub sample - which appears to be a considerable under-representation ${ }^{6}$ Krcmar noted that in her sample of Asian retailers there were no people who arrived before partition (1947) from the Punjab which probably suggests that the earlier settlers may have probably graduated from peddling to other businesses, and some went into wholesale, a story we chronicle in a future paper.

Table 4: Previous Business Experience (Retailers) 4 (Retailers)

\begin{tabular}{lcccc}
\hline & $\begin{array}{c}\text { India } \\
(\%)\end{array}$ & $\begin{array}{c}\text { Pakistan } \\
(\%)\end{array}$ & $\begin{array}{c}\text { Village } \\
(\%)\end{array}$ & $\begin{array}{c}\text { Town } \\
(\%)\end{array}$ \\
\hline Yes, Retail & 9 & - & 4.5 & 4 \\
Yes, Other & 9 & 4 & 1.0 & 15 \\
None 74 & 96 & 90 & 77 & \\
Don't Know & 9 & - & 45 & 4 \\
\hline
\end{tabular}

*Source - Reconstructed from Krcmar 1982

Of the total 41 retailer respondents surveyed by Krcmar 23 (54\%) amongst retailers originated from villages in Punjab. ${ }^{7}$ A similar figure was observed for our random sample survey in which $51 \%$ of the respondents were from rural areas. This certainly seems to suggest that exposure to city life does not appear to be a major contributory factor to the 
generation of self-employment enterprise despite the observation that those from the cities in the Panjab were four times more likely to have business experience in their country of birth. (Table 4).

In so far as business experience of all the respondents is concerned, Krcmar noted that only $16 \%$ had come from families with shop experience in the country of their birth with $32 \%$ having had mainly agricultural experience (Table 5). ${ }^{8}$ It appears that whilst the manual workers were the main contributors (48\%) to the Scottish pool of retailers, it is the combination of white-collar workers and agriculturalists which appear to be contributing (62\%) most to the Asian pool. One thing is almost certain that Asians were no more likely to have the shop keeping experience in the family than their Scottish counterparts in terms of family background (Table 5).

Table 5: Socio-Economic Background of Asian Retailers compared with Scots

\begin{tabular}{lcc}
\hline & Asian (\%) & Scottish (\%) \\
\hline Professional & 16 & 5 \\
Clerical & 14 & 14 \\
Skilled Manual & 8 & - \\
Labourer Unskilled & 26 & 42 \\
Farmer Landowner & 12 & - \\
Shop & 16 & 18 \\
Other & 8 & 5 \\
N= & 50 & 43 \\
\hline
\end{tabular}

*Source - Reconstructed from Krcmar 1982

Table 6: Business Type (Retailers)

\begin{tabular}{lccc}
\hline & $\begin{array}{c}\text { Indian } \\
(\%)\end{array}$ & $\begin{array}{c}\text { Pakistani } \\
\mathbf{( \% )}\end{array}$ & $\begin{array}{c}\text { Asian } \\
\mathbf{( \% )}\end{array}$ \\
\hline Mixture & 30 & 20 & 28.8 \\
Grocery & 44 & 48 & 44.2 \\
Hardware & 4 & 8 & 5.8 \\
Newsagent & 13 & 4 & 7.7 \\
Clothing & 4 & 8 & 5.8 \\
Video* & - & 4 & 1.9 \\
"Ethnic" & 4 & 8 & 5.8 \\
N= & 23 & 25 & 48 \\
\hline
\end{tabular}

* Video shops handled both English and Indian films/ tapes. Source Survey - sub sample - M. Luthra 1982.
Socio Economic Background in the U.K.

Of the total retailers the majority ran general stores with some diversification into video shops (Table 6) sector in contrast to the diversification scene in London where the Asian retailers had already moved into electronic and furniture shops, pharmacy and clothing, etc. It is also interesting to note that an expansion of off-license sub-sector had not taken place in Glasgow unlike London ${ }^{10}$ probably because of religious profile of the Asian community. As regards reasons for entry into retail these don't differ a great deal between Scottish and Asian retailers.

As to the previous work background in Glasgow 29\% of the retailers were in factory work, $23 \%$ (mostly from agricultural background) or worked in transport and $8 \%$ were professionals mostly of Indian origin. Among the Scots the clerical workers along with factory workers emerged as major groups from which the retailers were drawn. (Table 7 ). Of the total $12 \%$ were made redundant prior to setting up business most originated from transport or factories and were of Pakistani origin. Only $14 \%$ of retailers had any previous experience of shop keeping in the U.K. prior to establishing business significantly less when compared to $19 \%$ of the Scottish shop keepers.

Table 7: Country of Birth by Last Job in Glasgow

\begin{tabular}{|c|c|c|c|c|}
\hline & $\begin{array}{c}\text { India } \\
(\%)\end{array}$ & $\begin{array}{c}\text { Pakistan } \\
(\%)\end{array}$ & $\begin{array}{c}\text { Total Asian } \\
(\%)\end{array}$ & $\begin{array}{c}\text { White } \\
(\%)\end{array}$ \\
\hline Professional & 13 & 4 & 8 & 5 \\
\hline Clerical & 4 & - & 2 & 14 \\
\hline Factory & 17 & 28 & 29 & 42 \\
\hline Restaurant & 4 & 4 & 4 & - \\
\hline Shop & 9 & 20 & 13.5 & 19 \\
\hline Transport & 22 & 24 & 23 & - \\
\hline $\begin{array}{l}\text { Supervisory } \\
\text { skilled }\end{array}$ & 9 & 4 & 8 & 16 \\
\hline Unemployed & - & 4 & 2 & - \\
\hline Other & 22 & 12 & 19 & 5 \\
\hline$N=$ & 23 & 25 & 50 & 43 \\
\hline
\end{tabular}

Indicative evidence also suggests that desire to own businesses was particularly high among Asian 
manual workers. Indians were more likely to mention family tradition as a reason for going into retail. Although overall the Scots were certainly not less likely than Asians to give this reason (Table 8). The absence of alternative mentioned seems to suggest that there may have been some funneling into retail

Table 8: Reason for Entering Retail

\begin{tabular}{lcc}
\hline & $\begin{array}{c}\text { Asian } \\
\text { (\%) }\end{array}$ & $\begin{array}{c}\text { White } \\
\text { (\%) }\end{array}$ \\
\hline Easiest way of making a living & 56 & 54 \\
Family Tradition & 10 & 14 \\
No Particular Reason & 16 & 7 \\
Relatives Advice & 6 & 9 \\
Money & 4 & - \\
Spouse in Business & 2 & 5 \\
No Alternative & 4 & - \\
Knew Shop was For Sale & - & 2 \\
Don't Know & 2 & 9 \\
N = & 50 & 43 \\
\hline
\end{tabular}

*Source as before self-employment and with reasonable numeracy it was and perceived easier way to make a living.

Insofar as education is concerned the evidence appears to be contradictory, Krcmar found $35 \%$ of the retailers to be holding a degree of which $7 \%$ were U.K. degrees holders. We found not to be the case in our sub sample of self-employed or the shop keepers. One thing however was clear that retailers were less likely to have C.S.E. or equivalent qualifications than the other self-employed as well as the general Asian population, on the other end of the spectrum they were more likely to be graduates (Table 9). On balance if one keeps other studies and Krcmar's evidence in mind one could conclude safely that the Asian retailer's profile was more likely than general Asian population to be polarized in terms of their formal education. This seems more so when compared with retailers in English cities. It must also be noted that many researchers may have exaggerated the educational factor as they perceived Asian degrees to be equivalent to the U.K. degrees. ${ }^{11}$

Table 9: Education of Glasgow Self-employed, Retailers and General Household

\begin{tabular}{|c|c|c|c|c|c|c|}
\hline & $\begin{array}{c}* * * \text { Asian H } \\
\text { of } \mathrm{H}(\%)\end{array}$ & $\begin{array}{l}\text { *** Asian Not } \\
\text { S/Emp HH (\%) }\end{array}$ & $\begin{array}{l}{ }^{* * *} \text { Asian S/ } \\
\text { Emp HH (\%) }\end{array}$ & $\begin{array}{c}\text { ** Asian Shops } \\
\text { Keepers (\%) }\end{array}$ & $\begin{array}{c}\text { ** White Shop } \\
\text { keeper }(\%)\end{array}$ & $\begin{array}{l}\text { Inner } \\
\text { England }\end{array}$ \\
\hline None & 49.3 & 48.5 & 48 & 40 & 79 & 43 \\
\hline SLC & 24 & 23.7 & 23.5 & - & - & 22 \\
\hline CSE & 6 & 6 & 6 & 6 & - & \\
\hline O 'level' & 6 & 6 & 6 & - & 4 & 6 \\
\hline A 'level’ & 2.7 & 2 & 4 & 8 & 2 & 42 \\
\hline \multicolumn{7}{|c|}{ ONC/HNC/ } \\
\hline Tech & 2.7 & 1 & - & 8 & 15 & 5 \\
\hline Degree & 8 & 9 & 6 & 27 & - & \\
\hline Deg UK & 2.7 & 3 & 2 & 8 & - & 20 \\
\hline Other & 0.7 & - & 2 & 2 & - & 2 \\
\hline $\mathrm{N}=$ & 145 & 97 & 48 & 48 & 43 & 55 \\
\hline
\end{tabular}

*Sources ***M. Luthra Survey 1982

*Krcmar 1982 Asian Retailers in Glasgow, Strathclyde Business School

*McVoy D Asian Retailers Shakti June 1981 (Study of Ealing, Leicester and Bradford)

= Brown C. Black and White Britain PSI 1982

By and large the evidence appears to suggest that on the whole Asian retailers originate from a diverse background including both manual workers as well as professionals ostensibly as with the Scottish profile. A closer examination that the "dissatisfied professional" and Indian /Pakistani degree holder 
appears is small but significant contingent as contributor to the Asian entrepreneurial pool unlike the Scots where the manual workers from the factory together with the supervisory skilled worker appear to be the main contributors to the pool (Table 8). In fact, majority of the ex-professionals pointed out that they could not get deserving job commensurate with their subcontinent qualifications. In earlier days of settlement jobs such as a bus conductor provided a good wage pension and security and had a reasonable status ${ }^{12}$ but gradually it became de-stat used as community aspirations developed. So many moved into retail.

It is also interesting to note from Table 7 that very few restaurant workers became retailers. This in our view is since most of such workers tend to go into catering or restaurant business once they master some skills. ${ }^{13}$ The substantial proportion of manual workers entering retail were very similar among both the Asian and Scottish samples. There is evidence from Table 8 that quest for independence is a major factor and driving force in establishing retail business together with the ease with which it can be established given an already established framework of Asian economy such as cash and carry. ${ }^{14}$ Redundancy or unemployment did not appear to be disproportionate major investment source factors (Table 10 ). Only $10 \%$ of the retailers cited family tradition as a reason which is indicative of the lack of experience of Glasgow Asian communities in business partly due to the very low number presence of East Africans and Gujarati origin contingent.

Table 10: Country of Birth by Reasons for Leaving Last Job

\begin{tabular}{lcccc}
\hline & India & Pakistan & Asian & Scottish \\
\cline { 2 - 5 } & $\mathbf{( \% )}$ & $\mathbf{( \% )}$ & $\mathbf{( \% )}$ & $\mathbf{( \% )}$ \\
\hline Not a job suitable for qualifications & 5 & 5 & 4.8 & 7 \\
Money & 15 & - & 7.3 & \\
Shift Work & 10 & - & 4.8 & - \\
Redundancy & 5 & 20 & 12.2 & 10 \\
Desire to be self-employed & 62 & 35 & 48.8 & 39 \\
Wanted a change & 10 & 20 & 14.6 & 24 \\
Don't Know & 10 & 5 & 7.3 & 10 \\
Married & - & - & - & - \\
Lack of Promotion & - & - & - & 2 \\
N 21 & 20 & 41 & 43 & \\
\hline
\end{tabular}

*Source - Krcmar 1982

\section{Business Operation and Ethnic Niche}

The Scots were more likely to be owner shopkeepers or absentee shopkeepers who trended to employ people on a full-time basis to help run the shop Asian retailers were themselves employed full time but also both white and ethnic employees, mainly on a parttime basis (Table 11) and were supported by family member employees $98 \%$ of the Asian employees were 'family or related workers' in comparison with $78 \%$ of Scots. This partly explains the ability of the Asian retailers to work long hours including their extended capacity for Sunday opening (Table 12).
Table 11: Employee - Part Time

\begin{tabular}{lcc}
\hline & Asian (\%) & (\%) \\
\hline None & 39 & 21 \\
1 & 40 & 42 \\
$2-3$ & 17 & 30 \\
3 & 4 & 7 \\
$N=$ & 43 & 48 \\
\hline
\end{tabular}

*Source Krcmar 1982 
Table 12: Employees - Full Time

\begin{tabular}{lcc}
\hline & Asian (\%) & Scottish (\%) \\
\hline Owner only & 31 & 40 \\
Owner \& 1 Family & 52 & 35 \\
Owner \& 2 Family & 15 & 2 \\
Owner \& Outsiders & - & 7 \\
Owner not working in shop & 2 & 9 \\
Only Outsiders & - & 7 \\
$\mathrm{~N}=$ & 50 & 43 \\
\hline
\end{tabular}

*Source Krcmar 1982

The Asian retailers unlike their Scottish counterparts appear to be somewhat better placed to draw on the family or community labour to be able to open on Sundays (Table 13) although the surviving Scottish retailer appear to be matching the hours put in by his Asian counterparts during weekdays. (Table 14). Haq $^{15}$ showed that there has been a growth in number of part-time family employees in groceries as compared to other sub-sectors such as in the restaurant and wholesale sectors which show doubling of figures in employment at large.

Table 13: Sunday Opening Hours

\begin{tabular}{lcc}
\hline & Asian (\%) & Scottish (\%) \\
\hline Sunday Open & 80 & 28 \\
Sunday Closed & 20 & 72 \\
$\mathrm{~N}=$ & 50 & 43 \\
\hline
\end{tabular}

*Source - Krcmar 1982 Table

Table 14: Weekly Worked by Part-Time Workers

\begin{tabular}{lcc}
\hline Hours & Asian (\%) & White \\
\hline 14 & 12 & - \\
$12-14$ & 40 & 33 \\
$9-11$ & 34 & 37 \\
8 & 12 & 23 \\
8 & 2 & 7 \\
$\mathrm{~N}=$ & 50 & 43 \\
\hline
\end{tabular}

*Source Krcmar K. 1982
Insofar as the 'ethnic niche' is concerned it certainly did not exist at the time of the study according to Krcmar's data. (Table 15), we made a similar observation with regard to the low proportion of ethnic customers among the total number of ethnic customers in our Greenwich study (see Table).

Table 15: Ethnic Group of Customers Asian Retailers

\begin{tabular}{lc}
\hline Mostly White & No. \\
Asians Mostly & 76 \\
White and Asians & 8 \\
Mixed & 2 \\
Mixed & 4 \\
U.K. & 10 \\
\hline
\end{tabular}

*Source as before

\section{Capitalisation, Collateral and Establishment of Business}

Like many other spheres, the access to capital substantially governed by knowledge and networks into the system. Krcmar's analysis showed that $81 \%$ of the Scots knew about the source of capital and advice or went straight to the bank or capital in contrast to $67 \%$ of Asians who were more likely to go to another source.ie two and a half times more before approaching the bank for advice and that despite being more likely (12\%) than Scots $(3 \%)$ to have heard about the source of capital from a bank. They significantly relied on business colleagues / friends $(20 \%)$ in contrast to the Scots $(12 \%)$. So, what is lacked in terms of know how about the use of the bank is made up through other sources.

Insofar as the uptake of capital was concerned, $39 \%-40 \%$ of Asians used their own savings. $16-$ $23 \%$ relied on relatives for money but not as a main source, both figures being higher than the Scots. $24 \%$ of Asians used friends and of these $40 \%$ were the main resource. Of the total only $13 \%$ used ethnic banks as a source of loan a small but a significant figure (Table 16). Both groups appear to utilize Scottish banks for seeking loans to similar extents.

There appeared to be a higher tendency among those who were manual workers before entering 
retail to rely on their savings among Asians than others. In addition, Asians were twice as likely (29\%) to use their house as collateral in seeking loans in comparison with their Scottish counterparts. We found a similar tendency in our Greenwich survey where a quarter of the people used their house as a collateral for loans. ${ }^{16}$ Yet at the time Haq noted that $16 \%$ of the grocers and newsagents regarded lack of capital to be a constraint on anticipated growth, i.e., capital may be readily available for set up but perhaps not so readily for expansion. ${ }^{17}$

Table 16: Source of Capital

\begin{tabular}{|c|c|c|c|c|c|c|c|c|c|}
\hline & $\begin{array}{l}\text { Use } \\
\text { Yes }\end{array}$ & $\begin{array}{c}\text { Indian Of } \\
\text { source } \\
\text { Major }\end{array}$ & $\begin{array}{c}(\%) \\
\text { Minor }\end{array}$ & $\begin{array}{l}\text { Use } \\
\text { Yes }\end{array}$ & $\begin{array}{c}\text { Pakistani } \\
\text { Of source } \\
\text { Major }\end{array}$ & $\begin{array}{c}(\%) \\
\text { Minor }\end{array}$ & $\begin{array}{c}\text { Scots } \\
\text { Use } \\
\text { Yes }\end{array}$ & $\begin{array}{c}\text { Of all } \\
\text { source } \\
\text { Major }\end{array}$ & $\begin{array}{l}(\%) \\
\text { Minor }\end{array}$ \\
\hline Own Savings & 39 & 30 & 9 & 40 & 8 & 16 & 51 & 22 & 7 \\
\hline $\begin{array}{l}\text { Bank-ethnic } \\
\text { Bank - }\end{array}$ & - & 13 & - & 4 & 8 & - & - & - & - \\
\hline Scottish & 39 & 17 & - & 32 & 16 & 4 & 27 & 20 & 5 \\
\hline Friends & 17 & 4 & 9 & 4 & 16 & - & - & - & - \\
\hline Relative & 22 & - & - & 16 & 4 & 4 & 15 & 2 & 12 \\
\hline Redundancy & - & 4 & - & 8 & - & 4 & 5 & - & - \\
\hline $\mathrm{N}=$ & & 23 & & & 25 & & & 41 & \\
\hline
\end{tabular}

*Note: Figures do not add up to $100 \%$ as multiple-choice questions were asked.

*Source as before

\section{Property Relations Among Retailers}

Before we embark upon the analysis of commercial properties owned or leased by Asian retailers it would be relevant to note that both Asian retailers and self-employed are more likely to be owneroccupiers than their Scottish counterparts in terms of their residence than their Scottish counterparts ie $87 \%$ in contrast to the figure of $65 \%$ for Scottish retailers. The Scottish retailers rely a great deal more on council for residential accommodation (30\%) in contrast to Asian retailers (2.1\%).

Our own sample survey data suggested that $10 \%$ of the Asians owned more than one residential property while $3 \%$ owned more than two. The Asian investment in commercial property appears to be higher than investment in housing. $35 \%$ of the Asian retailers owned more than one business in contrast to $2 \%$ of Scots. Of these only $12 \%$ had second shops with different businesses whilst others were in the same business. We were unable to ascertain the nature of this investment. Analysis of valuation roll gave a firm impression of the existence of some 30 individuals mostly businessman who owned a number of commercial and residential properties in the Glasgow area. This observation was further supported by the presence of a significant number of Asian names on the University accommodation list. ${ }^{18}$

\section{Nature and Type of Property}

While $92 \%$ of the Scots leased their commercial property from the council only $30 \%$ of the Asians did, The latter figure although less than the Scots makes an interesting contrast to the figures we observed in relation to representation of Asian households at large in the public sector housing $(6 \%)$ in council accommodation only in 1983. Similarly the figure of $6 \%$ of Asian retailers living in the private rented sector which is the worst sector seems to be higher for the self-employed, although it could be possibly due to a number of retailers just establishing themselves.

Clearly in a commercial setting the response of Asian self-employed to the property market is quite different. It could on the one hand be attributed to slightly different attitudes towards commercial property or to do with the fact that Glasgow District Council owned a substantial number of properties in proximity to the Asian residential concentrations. 
An interesting observation to make is the extent in which the Scottish retailers rely on council accommodation for housing.

Table 17: Housing Tenure of Retailers

\begin{tabular}{lcc}
\hline & All Asian (\%) & Scottish (\%) \\
\hline Owner Occupier & 87 & 65 \\
Privately Rented & 6 & - \\
Council & 2 & 30 \\
Other/Don't Know & 4 & 4 \\
$\mathrm{~N}=$ & 50 & 43 \\
\hline
\end{tabular}

*Source as before

Thirty percent of Scottish retailers lived in council accommodation in contrast to $2 \%$ of the Asian retailers (Table 17). There is some evidence that secondary immigrants who moved to Glasgow to establish themselves tend to use the council accommodation as a stop gap in the early period of business establishment.

Also noticeable is the parallel to the observations we made in relation to age of the property owned by the Asians - the Asians were more likely to own older
Table 18: Tenure of Shop Premises

\begin{tabular}{lcc}
\hline & All Asian (\%) & Scottish (\%) \\
\hline Freehold & 46 & 23 \\
Leasehold & 52 & 77 \\
Don't Know & 2 & - \\
$\mathrm{N}=$ & 50 & 43 \\
\hline *Source as before & \\
& \\
tenement property than their Scottish counterparts \\
(Table 19) who were more likely to be in a modern \\
shopping arcade. While the Scottish distribution of \\
shops is across a wider spectrum of area types the \\
Asian shops are concentrated in tenement areas \\
(Table 19).
\end{tabular}

Given the fact that the majority of the Asian retailers lived locally their stake in the upper band of the housing market appears to be far less than their white counterparts, suggesting that the "housing type" may not a status symbol among Asians to the same extent as it appears to be amongst the Scottish retailers or it could be that they were having to split their resources between the two spheres of life they built an economic life and their security base.

Table 19: Housing Type of Owner

\begin{tabular}{lccc}
\hline & All Asian Retailers (\%) & Scottish Retailers (\%) & *Self Empl. Asians \\
\hline Detached & 6.5 & 9 & 3.9 \\
Semi-detached & 15 & 35 & 7.8 \\
Bungalow & 4 & 2 & - \\
Flat/Tenement & 67 & 39.5 & 80.3 \\
Terraced & 6.5 & 11 & 7.8 \\
$\mathrm{~N}=$ & 48 & 43 & 51 \\
\hline
\end{tabular}

*Source - Kcmar K Asian Retailers in Glasgow. M.B.A. Thesis. Strathclyde University Business School 1982.

Although Asians are twice likely to be freeholders of shops in $(46 \%)$ contrast to Scottish retailers $(23 \%)$, $70.7 \%$ of the properties they own were in less than $£ 1000$ ratable value band (Table 21 ) - a situation very similar to the one observed in a housing context. It was also observed that there was a significant movement of Asian shop businesses with at least of $30 \%$ of those found to be located in the middleclass high ratable areas although on the whole the pattern appeared to be of main concentration in the 'inner city areas'. As shown in Table 20, majority of the Asian retailers are conctraterin old two storey tenement buildings. Clearly some were making headway on new estates in the shopping arcades. 
Table 20: Housing Type

\begin{tabular}{lcc}
\hline & Asian (\%) & Scottish (\%) \\
\hline 1 storey old & - & 19 \\
1 storey modern & - & 5 \\
2 storey old & 73 & 53 \\
2 storey modern & 2 & - \\
Old shopping Arcade & 4 & 14 \\
Modern shopping Arcade & 15 & 9 \\
Other & 6 & - \\
$\mathrm{N}=$ & 50 & 43 \\
\hline
\end{tabular}

*M Luthra survey sub sample 1982

Table 21: Ratable Value Bands (of Shops Owned by Asians) 1982 (Asian Retailers Only)

Band Range Individual Bands Grouped Bands

\begin{tabular}{lcc}
\hline $0-599$ & 11.6 & 70.7 \\
$599-1400$ & 5.3 & 15.0 \\
$1400-2400$ & 0.8 & 9.9 \\
$2400-3199$ & 4.4 & 4.4 \\
No $=$ & 413 & 100 \\
\hline
\end{tabular}

*Source: Valuation Roll, Analysis by M Luthra 1982

The concentration of Scottish shops in industrial clearance areas was probably since many retailers purchased properties in declining areas as they were offered relatively cheap (Table 22) and bought with an eye on the hope value post development.

Table 22: Type of Area Location of Premises

\begin{tabular}{lcc}
\hline & Asian (\%) & Scottish (\%) \\
\hline Tenements & 71 & 39 \\
Modern Flats & 10 & 16 \\
Older Semi-detached & 8 & 12 \\
Modern Semi-detached & - & 2 \\
Industrial & - & - \\
Clearance & 6 & 26 \\
Renovated & - & - \\
Tenements & 6 & 5 \\
$\mathrm{~N}=$ & 50 & 43 \\
\hline
\end{tabular}

*Source: Krcmar K Asian Retailers in Glasgow 1982 - Strathclyde Business School
Business Acquisition, Location and Premises Insofar as more of business ownership was concerned the Asian retailers were only slightly more likely to be collective owners than white Scottish Glaswegian retailers. Of the total $40 \%$ of the Scottish retailers were in partnership as compared to $45 \%$ of Asians although Haqs analysis suggests the solo figure to be $94 \%$ which may indicate a huge but unlikely increase in sole proprietorship in a short period. This similarity should not be confused with the tendency of both groups to use ethnic solidarity to the same extent to generate business as the ratio of number of self-employed per capita are quite different, i.e., Scottish Glaswegians have to rely to a higher extent on formal partnership outside the family to get into and sustain their business.

Of the Asian respondents $35 \%$ had heard about their businesses through friends as compared to $28 \%$ of Scots when considering setting up business. Conversely the Scots were more likely to hear about business through direct contact (28\% Scots and $19 \%$ Asians) which appears to indicate a well-knit Scottish retailer's minority. This is also evident from the fact that the interviewers had difficulty constructing a sample of white retailers as there are so few white small businesses left in Glasgow. The confidence of Asian retailers is evident from the fact that $22 \%$ of Asian retailers had heard about the businesses on sale through newspapers in comparison with $14 \%$ of Scots. On the other hand, this could be indicative of the tight knit 'white Scottish market' albeit very small.

Krcmar's survey also showed that a majority (37\%) of the retailers first went into private business's during 1979-1982. For those who came direct to Glasgow, the figure was $50 \%$. Both figures are very (2.5 times to 4 times) high when compared with the percentage of length of residence figures for the same period. Only one fourth to one fifth businesses were established more than 10 years ago. $\mathrm{Haq}^{21}$ noted in his telephone survey that $64 \%$ of the retail business were established during 1970-1985 with $42 \%$ in the $1981-1985$ period. ${ }^{22}$

In most cases the current businesses were purchased from another running business retailer doing the same business (Table 23). $90 \%$ of the Asian respondents took over the same business but only $75 \%$ Scots did so. There appears to be 
a significant separation of markets with the Scots buying mainly from the Scots whilst some $60 \%$ of the Asian retailers purchased the business from Asians. (Table 24). This phenomenon of a separate market is quite similar to the one observed in relation to housing.

Table 23: Previous Business Type

\begin{tabular}{lcc}
\hline & All Asian (\%) & Scottish (\%) \\
\hline Same & 90 & 76 \\
Different & & 21 \\
Don't Know & - & 3 \\
$\mathrm{~N}=$ & 50 & 43 \\
\hline
\end{tabular}

*Source - as before

Table 24: Ethnicity of Previous Owner (Asian)*

\begin{tabular}{lccc}
\hline $\begin{array}{l}\text { Scottish } \\
(\%)\end{array}$ & $\begin{array}{c}\text { Pakistani } \\
(\%)\end{array}$ & $\begin{array}{c}\text { Indian } \\
(\%)\end{array}$ & $\begin{array}{c}\text { Not Known } \\
(\%)\end{array}$ \\
39 & 36 & 21 & 5 \\
$\mathrm{~N}=39$ & 14 & 8 & 2 \\
\hline
\end{tabular}

*All Scots in the sample acquired the business from a Scot (where known).

*Source - as before

\section{Proximity to Business Premises}

Generally, the Asian self-employed retailer's area a neighborhood phenomenon. This is apparent from the following observations made by Krcmar (Table 25).12\% of Asian lived on the premises while none of the Scottish sample did so. Scottish retailers were six times more likely to live more than 8 miles away. Similarly, $31 \%$ of the Asians lived within a mile only $19 \%$ of the Scots did so. Of the Asian sample $67 \%$ lived-in inner-city tenements / flats unlike $40 \%$ of the Scots. Generally, Asians were more likely than Scots to live near the shop.

Paradoxically when one examines the customer profiles there appears to be no significant differences between Asian and Scottish retailers view of the extent to which their customers are local (Table 26). This would partly be explained by extended networks of the Asian community which are perceived to be city wide now. This phenomenon of proximity to work does not appear to apply to employees in the catering trade to the same extent as the restaurants move out in the suburbs and small towns around Glasgow area. ${ }^{23}$ In the case of self-employed proximity to workspace enhances the ability to utilize the assistance of both the spouse and children.

Table 25: Distance of Home from Shop

\begin{tabular}{lcc}
\hline & All Asian (\%) & Scottish (\%) \\
\hline On Premises & 12 & - \\
1 mile & 28 & 19 \\
1-3 miles & 28 & 28 \\
$4-6$ miles & 22 & 28 \\
7-8 miles & 6 & 2 \\
8 miles & 4 & 23 \\
$\mathrm{~N}=$ & 50 & 43 \\
\hline
\end{tabular}

*Source - as before

Table 26: Proportion of Local Customers

\begin{tabular}{lcc}
\hline Percentage & All Asian (\%) & Scottish (\%) \\
\hline 90 & 44 & 47 \\
$60-89$ & 23 & 23 \\
50 & 8 & 5 \\
$20-49$ & 2 & 7 \\
20 & 10 & 18 \\
Don't Know & 14 & - \\
N = & 50 & 43 \\
\hline
\end{tabular}

*Source - as before

\section{Premises and Current Businesses}

As indicated in Table 27 the proportion of Asian and Scottish retailers who started on the current premises was quite similar for both ethnic groups indicating that the degree of establishment is similar for both communities, although the white Glaswegian movers did move relatively early (Table 27 ). Of the Asian respondents $75 \%$ moved in the last 5 years in contrast to $45 \%$ of Scots. Most of the movers did so partly due to dereliction as well as attraction of better business opportunities. The Asian commercial population appears to have been affected by dereliction of the same extent as the Glaswegian local retailer's population. (Table 29). Although the figure slightly lower than one for Asian 
residents' population which is because establishment

Table 27: Start of Business

\begin{tabular}{lc}
\hline Asian (\%) & Scottish (\%) \\
\hline Here & 6252 \\
Moved & 3945 \\
DK & 2 \\
& 5043 \\
\hline
\end{tabular}

*Source as before

Table 28: When Move

\begin{tabular}{lcc}
\hline & Asian (\%) & Scottish (\%) \\
\hline 1 year & 15 & 9 \\
1-2 years & 31 & 19 \\
3-5 years & 31 & 21 \\
6-10 years & 14 & 16 \\
11-15 years & 8 & 14 \\
7-15 years & - & 19 \\
DK & & \\
N & 50 & 43 \\
\hline
\end{tabular}

*Source - as before

Table 29: Why Move

\begin{tabular}{lcc}
\hline & Asian (\%) & Scottish (\%) \\
\hline Better Bus Opp. & 45 & 55 \\
Family Reasons & 5 & - \\
Demolition & 20 & 20 \\
Better Area & 20 & - \\
Easier & 5 & - \\
Other & - & 25 \\
K & 5 & - \\
& 50 & 43 \\
\hline
\end{tabular}

*Source - as before

of business a seventies phenomenon.

\section{Comparison With Other Studies}

We also undertook a comparative analysis with other studies to put our findings and observations in a perspective,
Glasgow customer ethnic niche appears to be probably existed in early days of settlement Glasgow retailers less likely to have parental business background.

Two business ownership proportion is high may be due to low rent and due to risk hedging and creat family member jobs.

Premise ownership is high with two business ownership making a good asset pooling and allows hedging.

Country of origin or local banks less utilized than expected.

Table 30: Comparison with Other Studies Some Differences

\begin{tabular}{lccc}
\hline & $*$ & $*$ & \\
LB Green- & All cities & Glasgow & \\
wich 1985 & 1978 & 1982 & \\
\hline Ethnic customers & 40 & 69 & 8 \\
Capital from banks & 82 & 64 & 39 \\
Own another business & 5 & 27 & 35 \\
Owned premises & 78 & 20 & 46 \\
Sole business & 72 & - & 55 \\
Collateral housing & 24 & - & 29
\end{tabular}

Source - Krcmar K Asian Retailers in Glasgow. M.B.A. Theses Strathclyde University. Business School 1982*Luthra and Bajwa (1985) Asian Retailers in LB Greenwich in London Indian Workers Association

**McVoy B 1982Shaktiand alsoMcEvoy, D., Jones, T., Cater, J., \& Aldrich, H., Asian Immigrant Businesses in British Cities, Paper Presented to the British Association for the Advancement of Science, Annual Meeting, September 1982

Housing ownership collateral although stated by only by one fourth of the respondents as playing a key role if doubled given two business owners is an interesting point to note. In addition, banks see an owner as a responsible payer and an asset owners instilling confidence in lending.

\section{Conclusions}

It appears that while most of the propositions stated at the beginning of the paper hold, some do not hold for Glasgow. First, there was a noted lack of an 'ethnic customers niche' in Glasgow playing any 
significant role in the establishment of Asian retail business development in the 1980s. This is not to say that such a niche did not exist during the sixties supporting the initial establishment of Asian business in the city. Secondly there is little evidence of Asian retailers having a significant background in retail or business, either in the U.K. or in the country of origin. A significant proportion originate from a peasant or agricultural background. In terms of their background in the U.K. most were either factory/manual workers or originated from transport and teaching sectors hence were slightly more likely to be professionals and graduates than their Scottish counterparts as well as the general self-employed.

Although the equivalent of an Indian graduate degree is deemed in the U.K. equivalent to ' $A$ ' level or less nevertheless the overall educational level is somewhat higher among Asians than the Scottish retailers. One should also take into that those who did not have qualifications amongst Asians are also quite likely to have low literacy in their own language. Redundancy and unemployment appear to contribute only to small extent to entry into retail as does the experience of discrimination. ${ }^{24}$ A word of caution is necessary though, issues such discrimination or redundancy do not surface in structured questionnaires very well for a variety of reasons including the guilt instilled into the victim.

A notable feature of origins is that very few restaurant workers entered retail perhaps focusing on the ample opportunity of entering the restaurant sector which also occupies a very large space in the Glasgow eating out cuisine economy. Another notable feature is the extent to which historically regarded noncommercial communities such as the Sikhs and Muslims are well represented in business despite their under-representation in commerce in the pre-partition Punjab. Majority of the business were established during the late seventies and there was little evidence of length of establishment of community as being a key factor in establishment of retail business. Retail was thought to be an easy option offering independence and move in on a tested ground following others and their advice and optimizing their resources.

The affordable tenements system appears to have enabled retailers to live nearby to the shop and engage in the local business enhancing the utilization of the local and family labour. The Asian retailers generally own or rent lower quality housing property which most probably enables them to transfer resources to business. Like their counter part property purchasers in housing, they have purchased at the cheap end of commercial property market often freehold or on short term loans paid off over a short period. There is however a significant number (at least one third) of shops are now located in what could be described as the middle-class areas generating kind of elite entrepreneurs.

The Asian retailers were well behind the Scottish retailers in terms of proportional access to the public sector commercial property although their access is many times better than the Asian population at large. They are also more likely to be owner occupiers in the commercial property market. The housing collateral appears to play significant markets which warrants further research as does their investment in petty landlord sector of which there was some evidence of early development.

As regards job to generation capacity of the retail sector it would be more appropriate to state that reasonable number of jobs were created for the family members with youngsters contributing significantly. The value of Asians businesses has to be seen in its social context similar to the value of co-ops. They play a significant role for the young society as training places, community centers, social control mechanisms in terms of controlling the young and keeping them off the dole register - all of these will have to be costed in a wider analysis.

There is evidence of a well-established 'ethnic market' in commercial property similar to the one observed in the case of housing which allows the business to be passed on within the Asian community usually through word to mouth. Asian retailers show slightly high activity in terms of movement from shop to shop although they are more likely to stick to tried and tested businesses.

They also appear to be well informed and established in the 'property market' and had almost ousted the indigenous Scottish Glaswegian retailer. In the 'capital information' market they still rely substantially on networks/colleagues for information although their utilization of Scottish bank loans is similar to those of the Scots. There appears to be little evidence 
of excessive reliance on savings for setting up the business among Asians. Ethnic banks appear to play some but limited role but on the whole mainstream banks provided for Asian business development.

Asian business appears to be not only moving into middle class areas they are also moving into 'public sector housing patches. Despite their substantial concentration in ethnic areas their reliance on 'ethnic custom' is not significant - which poses a question as to why this is the case particularly when one considers the fact that both Asian and Scottish retailer groups claim their custom to be local. The answer probably lies in the fact that there was an increased tendency among the indigenous population to shop locally together with the fact that the ratio of shops/capita ethnic population in Glasgow is so high that reliance on ethnic custom only would not have enabled the Asian retailers to survive.

Clearly the strategies adopted by of Asian and Scottish retailers appear to be different in relation to property. The Asian retailers seek to enhance equity value and aim for ownership at the cheaper end in both housing and commercial markets while the Scots are more likely to rely on renting both housing and business property so as to enhance their choice in terms of quality of property and the area. In addition, the Scots were slightly more likely to manage a shop on employee/absentee landlord model rather than the owner worker model and/or family co-op model. The former was based on 'formal contractual relationships' restricted to social hours and often lacks an injection of continuous commitment. This would partly explain the vulnerability of Scottish model in terms of its survival. To what extent the Asian model is a product of 'immigrant culture' and/or ethnicity is an open question. Why the Scots receded over the decades form retail shop keeping is another under researched question.

One difficulty of this kind of structured analysis is that it fails to probe into the actual thinking and the logic of the entrepreneurs in developing business elicit, i.e., the extent to which people follow other established people in their decision making in a kind of a herd mentality sense. Research using a non-positivist/ open ended approach is needed to give insights into why people from essentially agricultural background find it easier to become entrepreneurs despite the lack of qualifications and a background in business. They will certainly have us believe-it is easy

The apparent relationship between 'housing ownership' and commercial property or setting up of business among Asian retail appears to be partly due to that overlap of geography and partly by virtue of the housing acting as collateral. Clearly collateral does play a significant role although the Scottish banks attitudes towards lending for commercial property have been a willing one even to Scottish Glaswegian council tenants. Nevertheless, it is possible that for the newcomers it would have been important to show the indicative collateral to the bank before a loan is sanctioned and such a collateral could also have been an important element in raising informal loans.

The capacity of the retailers to pay for a house and a shop and to acquire housing ownership in a short-term period of arrival whilst fulfilling many other commitments is a question which needs to be researched in terms of examination of the immigrant as an economist. One obvious observation worth noting is that is majority of cases ownership of the house comes first in the case of Asians in Glasgow for instance and then the shop although council or private sector accommodation may be used as a stop gap by some but rarely when setting up new business and moving to a new place.

As regards tangible benefits of going into retail mostly the evidence scanned in various studies is based on turnovers given by shopkeepers. It is somewhat naïve of the researchers to rely on such data. Besides business provides many fringe benefits such as being able to get business items for the house at cost price, tax free facility on a variety of expenditures such as car, petrol etc. Such analysis also often fails to consider the equity built in the form of stock, or goodwill or general appreciation of the business and commercial property. It is often forgotten that the self-employed in general have a better control of their tax contribution to the treasury than salaried folks.

To cut a long story short, the hours may be long, the labour may be cheap but the overall return on a long-term basis is probably or may be little better than what the retailer would have earned in an 
alternative waged or salaried job. As to the middlemen minorities hypothesis given the evidence of hard work the hours and returns it is more like front line odd hoursservice minority.

On a comparative basis, Glasgow's retailer's ethnic customer niche if it ever existed disappeared probably in the early seventies. Glasgow's Asian retailers appear to have either limited 'business' experience in terms of family origins - partly because there is little representation of East African Asian or Gujaratis' who are traditional long lineage business communities. Despite this lack a rigorous retail economy has been developed by Punjabis.

Responses of Asian and Scots to Property Ownership

\begin{tabular}{|c|c|c|}
\hline \multirow[t]{2}{*}{ Type of Property } & \multicolumn{2}{|l|}{ Responses } \\
\hline & Asians & Scots \\
\hline Residential property & Outright ownership & $\begin{array}{l}\text { Public sector housing and } \\
\text { mortgaged properties }\end{array}$ \\
\hline Exchange & Ethnic submarkets & Ethnic submarkets \\
\hline Commercial property & $\begin{array}{l}\text { Reliance on family resource and } \\
\text { banks (some ethnic banks) }\end{array}$ & Reliance on banks and savings \\
\hline Commercial property & Some public sector access & Significantly public sector \\
\hline Commercial property & Outright and sole ownership & $\begin{array}{l}\text { Leasehold and collective } \\
\text { ownership }\end{array}$ \\
\hline $\begin{array}{l}\text { Retailers Housing } \\
\text { Location }\end{array}$ & $\begin{array}{l}\text { Public sector housing stop gap only } \\
\text { Infer city but one third moving } \\
\text { into better areas }\end{array}$ & Public sector access long term \\
\hline
\end{tabular}

The high proportion of graduates among Glasgow Asian retailers in comparison with other areas is probably a function of high proportion of city dwellers both of which explain the entry into shops via public sector employment, i.e., teaching and transport. Nevertheless, half the Asian retailer's sample had no 'qualifications. In one sense it could be argued that a variety of dormant skills in the community are collectively utilized by the whole community including those who were uneducated and or felt deskilled. Ownership of shops although not as high as seen in areas such as Greenwich in London when compared -nevertheless is quite high .Relatively lower proportion of Asian shopkeepers in Glasgow lived on the premises although most lived locally. This is since Scottish shops are usually not built on one up and one down model as in England and are part of a tenement block.

The commercial and housing property relations appear to interact through sharing of space which enables better use of labour, creates a territory which is an open one in terms of access to all customers. The common roots of its establishment can be traced back to areas of demolition, a niche economy supported at the time principally by family labour. Although diversification in retail remained poor (accept perhaps into video shops) expansion in the sector continued.

Local people at the time saw Asians economic risk taking as a chancers pathway in describing their risk whilst the Asians saw municipally supported and welfare coveted local culture as detrimental factor to locals to not being able to see opportunity spaces, they could see in Glasgow. With $30 \%$ of those located in the middle-class high ratable are at the time seedlings of commercially savvy business and small landlord class all pointed towards emerging community stratification within the Asian community.

Whilst the ethnic solidarity hypothesis holds as evident from somewhat segregated markets the ethnic niche customer hypothesis does not hold well for the Glasgow retailers ie "stranger" orientation did not appear to be affecting the solidarity and economic development of the Asian group and was not noted to be invoking hostility of the local Glasgow 
society at the time, nor did it foster resistance to assimilation, acquiring a "stranger" status as per prediction of the theory.

Although the asserted absence of postwar racism thesis has been challenged as alluded to below it is true that Glasgow never quite had the vexed manifest aggressive racism issues or street uprisings that other English metro cities did. As to the degrees of integration in terms of interethnic marriages socializing locally and friendships across communities both culture and religion may have some role to play. This we will explore in a future paper Suffice. To say that middleman minorities hypothesis does not hold well for Glasgow Asian community. The Glaswegians Asian retailers also differs in many significant in tackling its challenges and exploiting opportunities when compared with its English counterpart.

\section{A Look Ahead}

Early studies tended to focus on different immigrant groups living in close ties communities their limited their career opportunities in their places arrival countries. The clustering of immigrant groups, it was suggested enabled to optimize the use of a plentiful and flexible labour force aided by pooled, if limited capital; optimizing community resources. ${ }^{25}$ This was partly built on avoidance model Aldrich et al., ${ }^{26}$ McEvoy et al., ${ }^{27}$ and Jones et al., ${ }^{28}$ a desire to escape racial discrimination in the labourmarket or having to settle for low status jobs or unemployment.

Werbner ${ }^{29}$ Chaudry and Crick ${ }^{30}$ 'cultural resources' approach focused on cultural heritage which stresses thrift, industriousness and self-reliance contributing drivers. However, Barrett et al., ${ }^{31}$ in three UK cities with significant ethnic variations between the three: not mirrored in entrepreneurial outcomes between the three cities, the common themes being heavy concentration in low order retailing, long week and day working hours, poor returns, use of un-computed family labour and overdependence on low income local Asian customers. ${ }^{32}$ Ethnic minority self-employment rates including in retail is a product of ethno-cultural disparities but are also a function of differences in policy-legal regime and economic structural conditions. ${ }^{33}$

The future of these small businesses is under threat due to changes in external and internal business environment. ${ }^{34}$ The economic threat is captured by a study revealing a $25 \%$ decline in the number of Asian-run 'corner shops 'in England since the early 1990s, a trend which was expected to continue ${ }^{35}$ caused primarily by competition from large supermarkets opening small outlets almost next to such shops increasing intimidation often by young people and no desire on part of the progeny of the shopkeepers to follow parental footsteps ${ }^{36}$ in the sector. Indeed, a report by ABI Associates ${ }^{37}$ into the future of Asian-owned 'corner shops' recorded that $94 \%$ of owners did not want nor to expect their children to follow in their footsteps either.

It is also fair to say that whilst racism is detested by shop owners, there is little evidence to suggest that it is likely to contribute to the widespread closure of businesses, even though a few recent cases in England have revealed that years of racial abuse can take their toll and force small retailers to abandon their business. ${ }^{38}$ Ethnic minority businesses have put up with it for many decades and in Scotland the drug and alcohol fueled expression of abusive and intimidating racism in the evenings and what they see as effective policy processing of complaints All this does not encourage the young to follow into the family's footsteps as would be entrepreneurs. Indeed, the position of small retailers has been compounded by trading increasingly in low marginal economic conditions. A study in 2005 revealed that ethnic minority businesses, contribute around $£ 700 \mathrm{~m}$ to the Scottish economy on an annual basis. ${ }^{39}$ To foster continuous stream of younger generation of ethnic minorities an overarching comprehensive development approach is needed.

The immigrant as his own economist interacting with multiplicity of factors both in the context of carrying the legacy of its own socio economic communityhistory from the land they hail from, the resources they bring with them in terms of skills education capital and money management experience and how these interact with the ecological (i.e., an local economic factors and the policy framework the discrimination felt and its avoidance or accommodation or assistance from earlier settled communities their cultural orientation in economic context) of the situation they find themselves in.

These are many drivers, influencers and funnelers which shape the choices and channeling of the 
immigrant as astruggling economist often a family man in a strange land and who aspires to be an asset securer to enhance his families security optimizing the use of its family labor and personal resources seeking recognition and status in the host society and in the place of origin and making best of the multiplicity of risks and challenges including responding to local policy and encountered discrimination. This is his struggle (as opposed to more established notion of "class struggle" popularly acknowledges in the realm of sociology) often remains unrecognized by the left often dismissing them as petite bourgeois. His out of hours at a stone's throw service and the input of his family tend to be not recognized nor at the hazards of harassment and theft to the extent it shuld be.

The immigrant settlement economics needs a paradigm shift with a multidisciplinary non positivist approach to include economic psychology and socio-economic history of both migrating and settling groups and the environment they arrive in to feed into a unified theory of settlement economics and their advancement embracing some of the partial but useful models alluded in this paper. This paper is an attempted small contribution towards this aspiration.

This paper is part of a constructing socio economic history of the minorities project exploring the profile and the process of economic development and embeddedness of the Asian business in Glasgow who continue to occupy a major economic space in the shop keeping sector in the city.

\section{Acknowledgment}

Thanks are due to Professor Jyoti Atwal and Ms Anisha Deswal for their kind assistance in refining layout

\section{Funding}

The author(s) received no financial support for the research, authorship, and/or publication of this article.

\section{Conflict of Interest}

The authors do not have any conflict of interest.

\section{References}

1. Light, Ivan H., Ethnic Enterprise in America: Business and Welfare Among Chinese, Japanese, and Blacks, University of California Press, Berkeley, 1972; Light, Ivan \& Dana, Léo-Paul, Entrepreneurs and Capitalism Since Luther: Rediscovering the Moral Economy, Lexington, Landham, 2020.

2. Blalock, Hubert. Toward a Theory of Minority-Group Relations. New York: Capricorn Books, 1967 pp79-84), Edna Bonacich1973/10/1American sociological review American Sociological Association

3. For an overview, see, Ward, R., \& Jenkins R., (Ed.), Ethnic Communities in Business: Strategies for Economic Survival, Cambridge University Press, Cambridge, 1985. Also see, Wilson, P., Black Business Enterprise in Britain: A Survey of Afro-Caribbean and Asian Small Business in Brent, Runnymede Trust, London, 1983; Robinson, V., \& Flintoff, I., Asian Retailing in Coventry, New Community, 10(2), Winter 1982, p.p. 251-258. Ethnic advantage and minority business development. In Ward
R, Jenkins R (eds) Ethnic Communities in Business: Strategies for Economic Survival. Cambridge: Cambridge University Press

4. Krcmar K., Asian Retailing in Glasgow, M.B.A. Dissertation, Strathclyde University, Glasgow, Scotland, 1984. Krcmar also shared some data she did not utilse herself.

5. Amongst retailers wanting to add more shops or aspiring retailers there was a pent-up demand.

6. The emergence of Azad Video as a major chain added to the number of video shops.

7. Haq, Mohamad, Ethnic Minority Businesses, Dissertation Based on Telephone Survey, University of Glasgow, Glasgow, Scotland, June 1988.

8. Krcmar, Asian Retailing.

9. Ibid.

10. This may be due to the forbidden trading in alcohol amongst muslim retailers.

11. Islam forbids alcohol drinking and selling and over half of the population belonged to the Muslim faith.

12. This process appears to have taken place 
to lesser extent in the USA where such qualifications are accepted.

13. In early days within Asian communities, it was thought to be prestigious to have a postman or a conductor or drivers 's job being secure and well pensioned with defined hours and overtime.

14. Interview with Mohinder Singh-Barman, Ramana Sauchiehall Street.

15. The presence of Asian Cash and Carry sector obviously helps in their process as indicated by several people interviewed.

16. Haq, Ethnic Minority Businesses, p. 47.

17. It is harder to get funds for expension in retail too much evilable is needed by the bank

18. Haq, Ethnic Minority Businesses, Telephone Survey, p. 20.

19. Most of there were in the Hillhead area and a significance number catering for overseas students.

20. Haq, Ethnic Minority Businesses.

21. Krcmar, Asian Retailing.

22. Haq, Ethnic Minority Businesses.

23. Ibid., p. 12.

24. Such restaurants were observed in Bearsden (Amritsar, Chandigarh Preet, etc., mainly Indian).

25. Dunlop explored this in the context making a somewhat unconvincing case for job market discrimination leading to kind of funneling. Dunlop, E. A., Aspects of Scottish Migration History with Particular Emphasis on Contemporary Pakistani and Bangladeshi Migration, MLitt(R) Thesis, University of Glasgow, Glasgow, Scotland, 1988. Mohammed Ishaq, M., Hussain, A., \& Whittam, G., Racism: A Barrier to Entry? Experiences of Small Ethnic Minority Retail Businesses, International Small Business Journal: Researching Entrepreneurship, 28(4), 2010, p.p. 362-377.

26. Ram, M., \& Jones T., Ethnic Minority Business: Developments in Research and Policy, in K. Hafeez, D. McEvoy \& K. Hooi (Eds.), Changing Faces of Ethnic Entrepreneurship, The University of Bradford, Centre for Ethnic Entrepreneurship, Bradford, 2007.

27. Aldrich, H., Cater, J., Jones, T., \& McEvoy, D., Business Development and Self-Segregation: Asian Enterprise in Three British Cities, in C. Peach, V. Robinson, \& S. Smith (Eds.), Ethnic Segregation in Cities, Croom Helm, London,
1981; Aldrich, H., Jones, T., \& McEvoy, D., Ethnic Advantage and Minority business Development, in R. Ward, R. Jenkins (Eds.), Ethnic Communities in Business: Strategies for Economic Survival, Cambridge University Press, Cambridge, 1984.

28. McEvoy, D., Jones, T., Cater, J., \& Aldrich, H., Asian Immigrant Businesses in British Cities, Paper Presented to the British Association for the Advancement of Science, Annual Meeting, September 1982, cited in Jones, T., McEvoy, D., \& Barrett, G., Labour Intensive Practices in the Ethnic Minority Firm, in J. Atkinson, D. Storey (Eds.), Employment, the Small Firm and the Labour Market, Routledge, London, 1994.

29. Jones, T., McEvoy, D., \& Barrett, G., Labour Intensive Practices in the Ethnic Minority Firm, in J. Atkinson, D. Storey (Eds.), Employment, the Small Firm and the Labour Market, Routledge, London, 1994.

30. Werbner, P., Renewing an Industrial Past: British Pakistani Entrepreneurship in Manchester, Migration, 8, 1990, p.p. 7-39.

31. Chaudry, S., \& Crick, D., Small Asian-owned Retail Businesses in the UK: An Exploratory Investigation, Marketing Intelligence and Planning, 21(6), 2003, p.p. 346-356.

32. Barrett, G., Jones, T., McEvoy, D., \& McGoldrick, C., The Economic Embeddedness of Immigrant Enterprise in Britain, International Journal of Entrepreneurial Behaviour and Research, 8(1), 2002, p.p. 11-31.

33. Ibid., p. 17.

34. Ibid., p. 14.

35. See, Bent, R., Seaman, C., \& Wallace, A., Convenience Stores and the Ethnic Retailer: Independents Under Pressure and Threat, Queen Margaret University College, Edinburgh, 1999; O'Shea, S., Asians Cornered in Shops, Scotsman, 5 December 1997; Voyle, S., Asian Shopkeepers Under Threat from Tesco's, Financial Times, 14 November 2002, p. 2; Ritchie, G., Closing Time for the Corner Shop, Mail on Sunday, 16 July 2006, p. 16.

36. Brown, P., Family-run Asian Shops Disappear, Guardian, 5 January 2002; Barrett, G., Jones, T., \& McEvoy, D., Socio-Economic and Policy Dimensions of the Mixed Embeddedness of Ethnic Minority Business in Britain, Journal of Ethnic and Migration studies, 
27(2), 2001, p.p. 241-258.

37. Bachkaniwala, D., Wright, M., \& Ram, M., Succession in South Asian family businesses in the UK, International Small Business Journal, 19(4), 2001, p.p. $15-27$.

38. ABI Associates Limited, The Future of Asian Owned Cornershops in the New Millennium, ABI Associates, London, 1999.
39. Powell, A., After 14 Years of Misery, I'm Shutting Up Shop, Daily Mail, 14 April 2005, p. 3.

40. Deakins, D., Ishaq, M., Smallbone, D., Whittam, G., \&Wyper, J., Minority Ethnic Enterprise in Scotland: A National Scoping Study, Scottish Executive, Edinburgh, 2005. 